\title{
A SPECIFIC INHIBITOR FOR HUMAN DESOXYRIBONUCLEASE AND AN INHIBITOR OF THE LUPUS ERYTHEMATOSUS CELL PHENOMENON FROM LEUCOCYTES ${ }^{1}$
}

\author{
BY NATHANIEL B. KURNICK, LAWRENCE I. SCHWARTZ, SANFORD PARISER,? \\ AND STANLEY L. LEE \\ (From the Department of Medicine, Tulane University School of Medicine, New Orleans, \\ Louisiana; and the Hematology and Pathology Laboratories of the Mount Sinai \\ Hospital, New York, N. Y.)
}

(Submitted for publication September 29, 1952; accepted December 3, 1952)

In speculating upon the probable role of desoxyribonuclease (DNase) in the depolymerization of desoxyribonucleic acid (DNA), which characterizes (1) the "lupus erythematosus (L.E.) cell" (2), we have suggested (3), as have Klemperer and his associates (4), that an increased serum enzyme activity, potentiation of an intracellular DNase, or destruction of an intracellular inhibitor of DNase by a serum factor, might be responsible. In a previous communication (5) we reported evidence which excludes the serum DNase from responsibility for the phenomenon. Studies on the interaction of leucocytes and serum, in an approach to the alternative possibilities, disclosed the presence of a specific intracellular inhibitor of human serum DNase and an inhibitor of the "L.E. cell" phenomenon $(6,7)$. In the present paper, we shall report upon some of the characteristics of these factors.

\section{SERUM DNASE INHIBITION}

\section{A. Preparation of leucocyte extracts}

Leucocytes (WBC) were prepared with the aid of Bovine fraction I from heparinized blood as previously described (5) or by centrifugation at 0 to $2^{\circ} \mathrm{C}$ of fresh "ACD" blood ${ }^{8}$ (120 ml. of 1.47 per cent dextrose, 1.32 per cent sodium citrate, 0.48 per cent citric acid plus 480

1 This work was aided by grants to Tulane University School of Medicine (N. B. K.) from the National Heart Institute, U.S.P.H.S. (No. H-714), the American Heart Association, American Cancer Society (recommended by the Committee on Growth, National Research Council) and the Life Insurance Medical Research Fund, and to the Mount Sinai Hospital from the Life Insurance Medical Research Fund and A. A. List.

2 Anna Ruth Lowenberg Fellow in Hematology, Mount Sinai Hospital.

- We are indebted to Dr. J. W. Davenport and Mr. John Gavey of the Medical Department of the New Orleans Regional Blood Center, American Red Cross, for generous supplies of human blood. ml. whole blood) followed by collection of the WBC layer and repeated washing at 0 to $2^{\circ} \mathrm{C}$ with $0.14 \mathrm{M} \mathrm{NaCl}$ until a good separation of WBC from erythrocytes was obtained. The latter technique was used with large volumes of human blood $(2500-3000 \mathrm{ml}$.).

Extracts of WBC were prepared by either of two methods :

(a) Suspensions of $24 \times 10^{\circ}$ or more WBC per $\mathrm{ml}$. in $0.14 \mathrm{M} \mathrm{NaCl}$ or heparinized plasma were lysed by repeated freezing in acetone-solid $\mathrm{CO}_{2}$ mixtures followed by thawing by immersion in a $37^{\circ} \mathrm{C}$ water bath. Complete disintegration of cells was accomplished by freezing and thawing four times. An aliquot was clarified by centrifugation at $2700 \times \mathrm{G}$ (measured at center of tube) for 30 minutes in a Sorvall angle centrifuge. The material was stored at $-20^{\circ} \mathrm{C}$.

(b) Approximately $12 \times 10^{\circ}$ fresh WBC were suspended in $30 \mathrm{ml} .0 .14 \mathrm{M} \mathrm{NaCl}$ at 0 to $2^{\circ} \mathrm{C}$ and blended in a micro Waring Blendor equipped with an ice jacket (8), slightly modified by the addition of a rubber diaphragm seal for the ice jacket, to permit pouring from the Blendor without contamination of the material by the ice-saline mixture in the jacket, for 10 minutes (sufficient for complete fragmentation of the cells, as demonstrated by microscopic examination). The homogenate was centrifuged for 15 minutes at $430 \times \mathrm{G}$. The supernatant, representing the bulk of the cytoplasmic material and some soluble nuclear components, was labelled "cytoplasmic fraction." This was separated by centrifugation for 40 minutes at $2700 \times G$ into a "cytoplasmic supernatant" and "cytoplasmic sediment." The sediment obtained from the whole homogenate at $430 \times \mathrm{G}$ was washed repeatedly with saline in order to obtain a clean "chromosomal fraction" and fractionated into nucleohistone (DNH) and "residual chromosomes" after Mirsky and Ris $(9,10)$. From DNH, purified desoxyribonucleic acid (DNA) was prepared according to Mirsky and Pollister (11). All fractions were resuspended in $0.14 \mathrm{M} \mathrm{NaCl}$ to reconstitute, approximately, the original concentration $\left(12 \times 10^{\circ} \mathrm{WBC}\right.$ in $30 \mathrm{ml}$.). All procedures were carried out at 0 to $2^{\circ} \mathrm{C}$. Upon completion of the fractionation, sodium ethyl mercuri-thiosalicylate was added to a final concentration of 1:100,000, and the material was stored at $-20^{\circ} \mathrm{C}$. A pale pink color was imparted to the cytoplasmic fraction and the supernatant obtained therefrom 
by the hemoglobin of the RBC which remained entrapped in the WBC layers.

\section{B. Inhibition of serum DNase}

Each of the WBC extracts prepared by the freezing-thawing method was tested for DNase activity by the methyl green method (3) as modified for serum (12). In no case was any DNase activity detected under these conditions of ionic strength and $\mathrm{pH}$. Tests for DNase activities under other conditions (13-17) were not made, since these would not interfere with our experiments. Tests for DNase inhibition against human serum were performed by substituting the fraction to be tested for part or all of the $3 \mathrm{ml}$. saline used in diluting the substrate (12). Simultaneous observations on the inhibition of the "L.E. cell" phenomenon by each of the fractions are reported be-

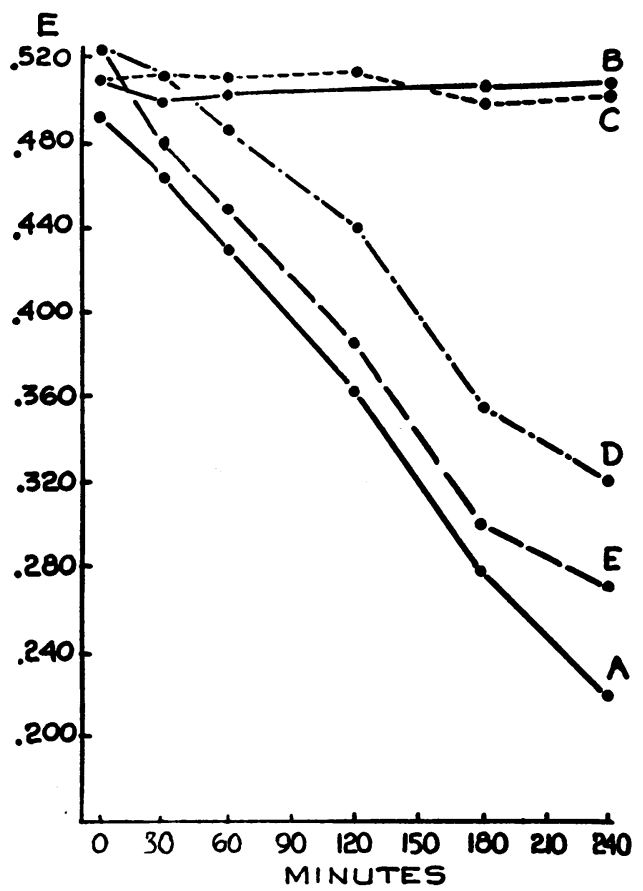

Fig. 1. Human Serum DNase Inhibition by Human LeUCOCYTE (WBC) Exrracts

Each point represents optical density of $3 \mathrm{ml}$. substrate-inhibitor-serum mixture added to $0.5 \mathrm{ml}$. $0.33 \mathrm{M}$ sodium citrate after incubation for intervals indicated at $37^{\circ} \mathrm{C}$. Each $19 \mathrm{ml}$. of the incubated mixture contains $1 \mathrm{ml}$. serum and $1 \mathrm{ml}$. of the following saline WBC extracts : A. None ( $1 \mathrm{ml} .0 .14 \mathrm{M}$ saline), B. Supernatant from $6 \times 10^{8}$ frozen and thawed cells, C. "Cytoplasmic supernatant," D. Unwashed "cytoplasmic sediment," E. Chromosome fraction. low. The observations on the two types of inhibition parallel each other closely. Rarely, preparations which had previously been found to contain inhibitor, failed to inhibit the "L.E. cell" phenomenon and only weakly inhibited human serum DNase. As will be seen, these failures were probably due to proteolysis (autolysis), whereas the discrepancies result from the greater sensitivity of the DNase system.

Inhibition of human serum DNase was observed with the frozen and thawed extracts, both before and after centrifugation, with the total "cytoplasmic fraction," and the "cytoplasmic supernatant" prepared from blended WBC. Neither the "cytoplasmic sediment" nor the "chromosomal fraction" (nor fractions prepared therefrom) demonstrated inhibition (Fig. 1).

The relationship between the amount of inhibitor present and the degree of inhibition is apparently not linear (Fig. 2), and resembles the curve reported by Zamenhof and Chargaff (13) for their yeast DNase inhibitor.

\section{Physico-chemical properties of inhibitor}

Prolonged dialysis against frequent changes of $0.14 \mathrm{M}$ saline at $0^{\circ} \mathrm{C}$ did not alter the inhibitory activity of extract fractions. No loss of inhibition resulted from heating at $56^{\circ} \mathrm{C}$ for 2 hours (both unbuffered and buffered at $\mathrm{pH} 7.5$ with trimethylol-amino-methane buffer [18]). Heating to $100^{\circ} \mathrm{C}$ in a boiling water bath for 30 minutes completely destroyed all inhibitory effect. The addition of citric acid to bring the final concentration to 1 per cent, followed by dialysis against saline at $0^{\circ} \mathrm{C}$ (to remove citrate), resulted in loss of inhibitory activity by "cytoplasmic supernatant." This was probably a $\mathrm{pH}$ effect, since treatment of inhibitors prepared by freezing and thawing cells into saline with $0.1 \mathrm{~N} \mathrm{NaOH}$ or $0.06 \mathrm{~N} \mathrm{HCl}$ also destroyed their inhibitory effect. However, $0.00025 \mathrm{~N} \mathrm{HCl}$ (as used in the pepsin digestion described below) did not affect inhibition.

Since the citrate ion is a potent inhibitor of DNase, it seemed possible that traces of this ion from the ACD solution might have been responsible for the inhibition of serum DNase by the "cytoplasmic supernatant." The following observations, previously noted, militate against this possibility :

(a) Potent inhibitors were prepared from heparinized blood, (b) $100^{\circ} \mathrm{C}$ destroyed the in- 


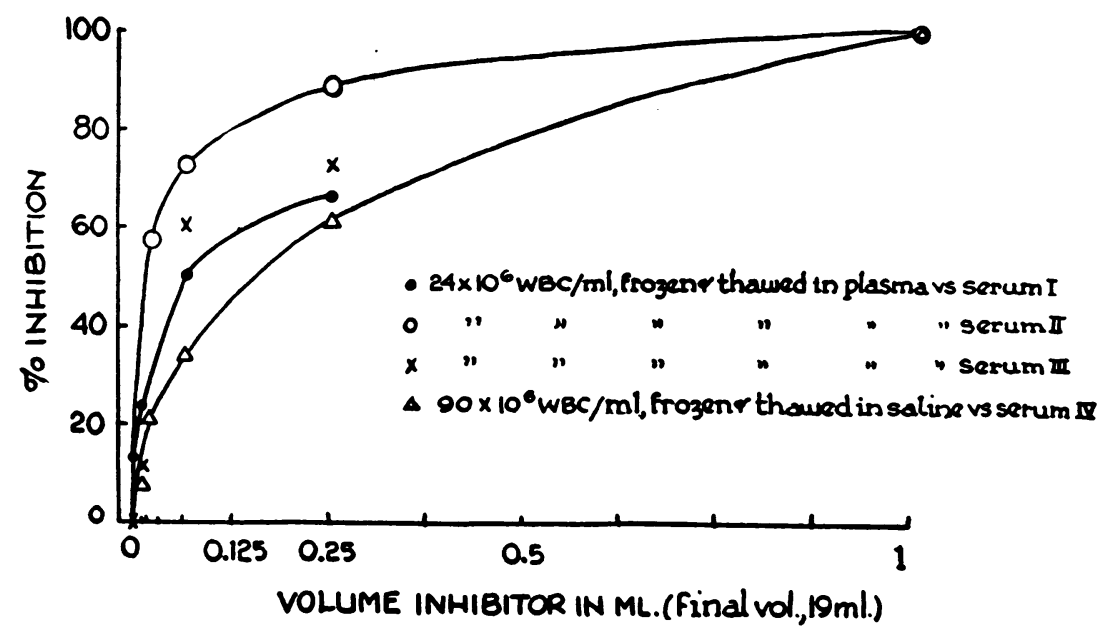

Fig. 2. Degree of In hibition of Serum DNase vs. Volume (Concentration) of In hibitor (19 ML. Final Volume of SubStrate-Inhibitor-Serum Mixture Containing 1 ML. Serum)

hibition, (c) 1 per cent citric acid, $\mathrm{NaOH}$, and $\mathrm{HCl}$ destroyed inhibition, and (d) dialysis did not reduce inhibition. This possibility was further excluded by a direct test:

To $20 \mathrm{ml}$. of a "whole chromosome" suspension, and of a "cytoplasmic sediment" suspension, $5 \mathrm{ml}$. of "ACD" solution were added. After an hour at room temperature, the material was dialyzed against $0.14 \mathrm{M} \mathrm{NaCl}$ at $0-2^{\circ} \mathrm{C}$ for 24 hours, with frequent changes of the bath. No inhibition of human serum DNase was detected with either material before or after the treatment with "ACD."

\section{Effects of enzymes}

"Cytoplasmic supernatant" inhibitors were incubated for 2 hours at $37^{\circ} \mathrm{C}$ with an equal volume of solutions containing $3 \mathrm{mg}$. per $\mathrm{ml}$. of the following enzymes ${ }^{4}$ in $0.01 \mathrm{M} \mathrm{pH} 7.5$ trimethylol-aminomethane buffer (18) : ribonuclease, trypsin, chymotrypsin, papain, and yeast protease. Ribonuclease was also used at $56^{\circ} \mathrm{C}$ for 2 hours. Pepsin was similarly used, but dissolved in water (final $\mathrm{pH}$ 4.7 ) or in $0.0005 \mathrm{~N} \mathrm{HCl}$. Two ml. of each mixture was tested for inhibitory effect against human serum DNase (final volume $19 \mathrm{ml}$. as in [12]). Controls consisted of the inhibitor incubated with the solvent (i.e., without enzyme) and of the enzyme incubated with saline (i.e., without inhibitor). The inhibitor controls showed unimpaired inhibitory action and the enzyme controls had no effect on serum DNase activity except in the case

4 Crystalline enzymes obtained from General Biochemicals, Inc., Chagrin Falls, Ohio. of yeast protease, which, alone, revealed DNase activity, and produced an additive DNase activity with sera. All of the proteolytic enzymes completely destroyed the inhibition of serum DNase, while ribonuclease was without effect upon the inhibitor.

\section{E. Permeability of cell membrane to inhibitor}

Since WBC were found to contain an inhibitor for human serum DNase, it appeared possible that the very low serum DNase values commonly encountered in normal sera (12) might result from exposure of the serum to the WBC of the blood before separation, particularly if separation was not carried out promptly. Freshly clotted blood was allowed to stand at room temperature and at $37^{\circ} \mathrm{C}$. Samples of sera were removed at intervals from 15 minutes to 6 hours after collection. Similar experiments were performed with heparinized blood. No change in DNase activity was observed over this period. After 24 hours at $37^{\circ} \mathrm{C}$, there was moderate reduction of DNase activity, but this was no greater than was noted when separated serum was allowed to stand for the same interval. The fact that no significant amount of inhibitor "leaked" into autologous serum or plasma was also supported by the observation that in no case was inactive serum found to inhibit the DNase of an active serum. However, $0.14 \mathrm{M}$ saline, allowed to stand in contact with isolated WBC at 0 to $2^{\circ} \mathrm{C}$ for 24 to 48 hours, ex- 
TABLE I

Inhibition of serum desoxyribonuclease by various cell types

\begin{tabular}{lcccccc}
\hline \hline \multicolumn{1}{c}{ Diagnosis } & $\begin{array}{c}\text { No. of cells } \\
\text { per ml. of } \\
\text { saline }\end{array}$ & $\begin{array}{c}\text { Lympho- } \\
\text { cytes }\end{array}$ & $\begin{array}{c}\text { Granulo- } \\
\text { cytes }\end{array}$ & $\begin{array}{c}\text { Mono- } \\
\text { cytes }\end{array}$ & $\begin{array}{c}\text { Blast } \\
\text { cells }\end{array}$ & $\begin{array}{c}\text { Inhibition. } \\
\text { per cent }\end{array}$ \\
\hline 1) Lymph. Leukemia & $20 \times 10^{\circ}$ & 14 & 6 & 0 & 0 & 32 \\
2) Normal & $35 \times 10^{\circ}$ & 15 & 18 & 2 & 0 & 39 \\
3) Monocytosis & $170 \times 10^{\circ}$ & 17 & 68 & 85 & 0 & 41 \\
4) Normal & $174 \times 10^{\circ}$ & 75 & 84 & 15 & 0 & 66 \\
5) Ac. Myel. Leukemia & $240 \times 10^{\circ}$ & 5 & 35 & 0 & 200 & 56 \\
6) Chronic Myel. Leukemia & $300 \times 10^{\circ}$ & 2 & 290 & 0 & 8 & 36 \\
\hline
\end{tabular}

tracted a significant amount of inhibitor from them, as demonstrated by inhibition of serum DNase by the supernatant. Furthermore, $60 \times$ $10^{\circ} \mathrm{WBC}$ washed four times with $0.14 \mathrm{M} \mathrm{NaCl}$, then frozen and thawed into $1 \mathrm{ml}$. of the test serum, produced only slight inhibition of DNase, while unwashed WBC, similarly treated, produced complete inhibition.

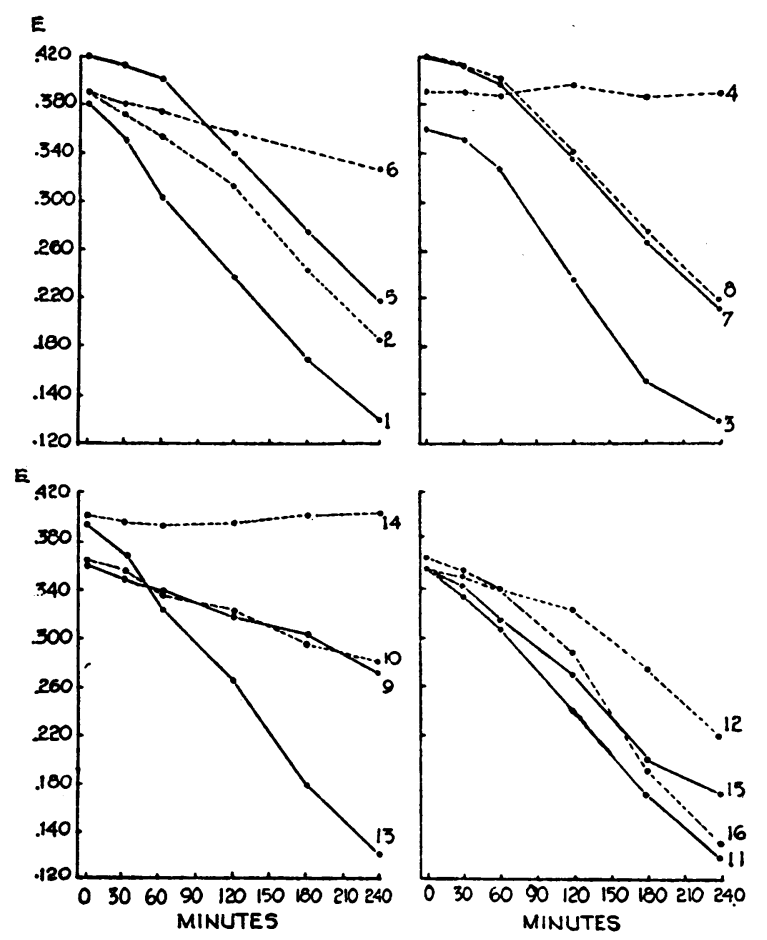

Fig. 3. In mibition of Various Desoxyribonucleases by Human WBC "Cytoplasmic Supernatant"

Solid line represents activity of substrate-serum alone; dotted line represents activity of substrate-serum mixture plus $1 \mathrm{ml}$. "cytoplasmic supernatant" (final volume $19 \mathrm{ml}$.). 1, 2. Dog serum, 3, 4. Rabbit serum, 5, 6. Guinea pig serum, 7, 8. Cat serum, 9, 10. Rat serum, 11, 12. Hamster serum, 13, 14. Human serum, 15, 16. Bovine pancreatic DNase.

\section{F. Inhibitor preparations from different cell types}

The presence of inhibitor in different types of cells was studied by freezing and thawing in $0.14 \mathrm{M}$ saline, WBC isolated from a normal person, a patient with post-splenectomy monocytosis (40,000 WBC per cmm. capillary blood, 50\% monocytes), a patient with chronic myelogenous leukemia, one with lymphosarcoma and lymphatic leukemia (70\% lymphocytes), and one with acute myelogenous leukemia. The effect of $0.5 \mathrm{ml}$. of the supernatant from each was tested against $1 \mathrm{ml}$. of a single serum sample (Table I).

The data suggest that lymphocytes may be richer in inhibitor than granulocytes (cf. 1 and 6) and that monocytes may be poor in inhibitor (cf. 3 and 4). The relationship found between the inhibition by $35 \times 10^{\circ}$ and by $174 \times 10^{\circ}$ normal WBC appears consistent with the data in Fig. 2. Immature leucocytes appear to be richer in inhibitor than mature WBC (cf. 5 and 6). Caution is necessary in interpreting these observations, however, since completeness of inhibitor extraction may vary among the cell types.

\section{G. Species specificity of inhibitor}

Nine different inhibitors prepared from human WBC were tested against the sera of dog (diluted $3: 4$ with saline), cat (diluted $3: 100$ ), rabbit (diluted 1:2), hamster (undiluted), guinea pig (diluted $3: 4$ ), rat (undiluted), and mouse (undiluted). Dilutions were selected so that $1 \mathrm{ml}$. of the diluted serum approximated the DNase activity of active human serum (about $140 \times 10^{-4}$ units per ml. serum [see (3) for the definition of DNase unit]). Bovine pancreatic DNase (19)" was similarly tested in a final concentration of $0.005 \mu \mathrm{g}$. per $\mathrm{ml}$. The results of a typical experi-

- Worthington Laboratories, Freehold, N. J. 
SPECIFIC INHIBITOR OF DESOXYRIBONUCLEASE AND "L. E. CELL"

TABLE II

Enhanced susceptibility of washed leucocytes to "L.E. cell" transformation

\begin{tabular}{|c|c|c|c|c|c|c|c|c|}
\hline \multirow[b]{2}{*}{$\begin{array}{l}\text { L.E. serum } \\
\text { dilution } \\
\text { (initial) }\end{array}$} & \multicolumn{4}{|c|}{ Unwashed WBC } & \multicolumn{4}{|c|}{ Washed $(4 X)$ WBC } \\
\hline & "Globs" & $\begin{array}{l}\text { "L.E.". } \\
\text { cells" }\end{array}$ & Rosettes & Total & "Globs" & $\begin{array}{l}\text { "L.E. } \\
\text { cells" }\end{array}$ & Rosettes & Total \\
\hline $\begin{array}{l}\text { Undil. } \\
1: 2 \\
1: 4 \\
1: 8 \\
1: 16\end{array}$ & $\begin{array}{l}2 \\
0 \\
0 \\
0 \\
0\end{array}$ & $\begin{array}{l}2 \\
1 \\
0 \\
0 \\
0\end{array}$ & $\begin{array}{l}1 \\
1 \\
0 \\
0 \\
0\end{array}$ & $\begin{array}{l}\mathbf{5} \\
2 \\
0 \\
0 \\
0\end{array}$ & $\begin{array}{l}2 \\
2 \\
2 \\
1 \\
0\end{array}$ & $\begin{array}{l}3 \\
2 \\
2 \\
0 \\
0\end{array}$ & $\begin{array}{l}3 \\
3 \\
2 \\
1 \\
0\end{array}$ & $\begin{array}{l}8 \\
7 \\
6 \\
2 \\
0\end{array}$ \\
\hline
\end{tabular}

ment are shown in Fig. 3. As indicated by the curves, only the human and rabbit DNase were completely inhibited. There was moderate inhibition of guinea pig and hamster serum DNase, questionable inhibition of canine DNase, and no inhibition of rat, cat, and mouse serum and bovine pancreatic DNase.

\section{II. "L.E. CELL" PHENOMENON INHIBITOR}

\section{A. Quantitation of "L.E. cell" phenomenon}

Sera with "L.E. phenomenon activity" (L.E. serum) were the same as those reported previously (5). Leucocyte (WBC) "buttons" of $10-15 \times 10^{\circ} \mathrm{WBC}$ were prepared as in that paper (5). These WBC "buttons" were used as substrate for the L.E. phenomenon without further treatment or after washing four times by resuspension in about $7 \mathrm{ml}$. isotonic saline and re-centrifugation. The "buttons" were suspended in $0.5 \mathrm{ml}$. saline (or inhibitor to be tested), $0.5 \mathrm{ml}$. of L.E. serum (diluted with normal serum) was added, and the mixture incubated at $37^{\circ} \mathrm{C}$ for 1 hour. The WBC were then sedimented by centrifugation for $\mathbf{5}$ minutes at low speed, smeared upon glass slides, fixed in absolute methyl alcohol for 5 minutes, and stained in dilute Giemsa solution for 30 minutes. The stained smears of a given experiment (with appropriate controls) were examined by a single observer who (to insure objectivity) did not know the labelling code. Each of the three morphological manifestations of the
L.E. phenomenon (a. classical "L.E. cell" with single large inclusion, or "droplet cell" with several small inclusions, b. rosettes, c. "globs" [5]) was graded from 0 to 4 on the basis of frequency of occurrence.

\section{$B$. Increased susceptibility of washed $W B C$ to "L.E. cell" transformation}

. It was regularly found that washed WBC were more susceptible to "L.E. cell" transformation than were unwashed WBC, as measured both by the intensity of the "L.E. cell" phenomenon at any given dilution of L.E. serum and by the titer to which the L.E. serum would tolerate dilution before loss of demonstrable L.E. activity (Table II). To exclude the possibilities (a) that the removal of the native plasma or the heparin and fibrinogen included therein and $(b)$ that the traumatization of the WBC by repeated centrifugation had caused their greater susceptibility to the "L.E. cell" transformation, two controls were added. In one, the washed WBC were resuspended in their original plasma, re-centrifuged, and tested. No diminution in the enhancement of the "L.E. cell" phenomenon produced by washing was observed. In the second control, unwashed WBC were resuspended in the original plasma and re-centrifuged

TABLE III

Inhibition of "L.E. cell" phenomenon by leucocyte homogenate"

\begin{tabular}{|c|c|c|c|c|c|c|c|c|}
\hline \multirow{2}{*}{$\begin{array}{l}\text { L.E. serum } \\
\text { dilution } \\
\text { (initial) }\end{array}$} & \multicolumn{4}{|c|}{ Control (normal plasma) } & \multicolumn{4}{|c|}{ Inhibited (WBC homogenate) } \\
\hline & "Globs" & "L.E." & Rosettes & Total & "Globs" & "L.E. & Rosettes & Total \\
\hline $\begin{array}{l}\text { Undil. } \\
1: 2 \\
1: 4 \\
1: 8 \\
1: 16 \\
1: 32 \\
1: 64\end{array}$ & $\begin{array}{l}2 \\
1 \\
1 \\
1 \\
1 \\
1 \\
0\end{array}$ & $\begin{array}{l}3 \\
2 \\
2 \\
1 \\
1 \\
0 \\
0\end{array}$ & $\begin{array}{l}3 \\
3 \\
1 \\
1 \\
0 \\
0 \\
0\end{array}$ & $\begin{array}{l}8 \\
6 \\
4 \\
3 \\
2 \\
1 \\
0\end{array}$ & $\begin{array}{l}2 \\
1 \\
1 \\
0 \\
0 \\
0 \\
0\end{array}$ & $\begin{array}{l}1 \\
1 \\
1 \\
0 \\
0 \\
0 \\
0\end{array}$ & $\begin{array}{l}1 \\
1 \\
1 \\
0 \\
0 \\
0 \\
0\end{array}$ & $\begin{array}{l}4 \\
3 \\
3 \\
0 \\
0 \\
0 \\
0\end{array}$ \\
\hline
\end{tabular}

* Washed WBC $\left(15 \times 10^{6}\right)$ plus $0.5 \mathrm{ml}$. normal plasma or WBC homogenate plus $0.5 \mathrm{ml}$. L.E. serum (diluted with normal serum).

** WBC homogenate consists of $40 \times 10^{\circ} \mathrm{WBC}$ per $\mathrm{ml}$. frozen and thawed in normal plasma. 
and resuspended four times. Such unwashed, but repeatedly resuspended and re-centrifuged WBC revealed no increased susceptibility to "L.E. cell" transformation. Controls in which normal sera, with and without DNase activity, were substituted for active L.E. sera revealed no "L.E. cell" induction in either washed or unwashed WBC.

\section{C. "L.E. cell" phenomenon inhibition}

The probability that the increased susceptibility of washed WBC to "L.E. cell" transformation was due to the partial removal from the WBC of inhibitor was confirmed by replacing the inhibitor.

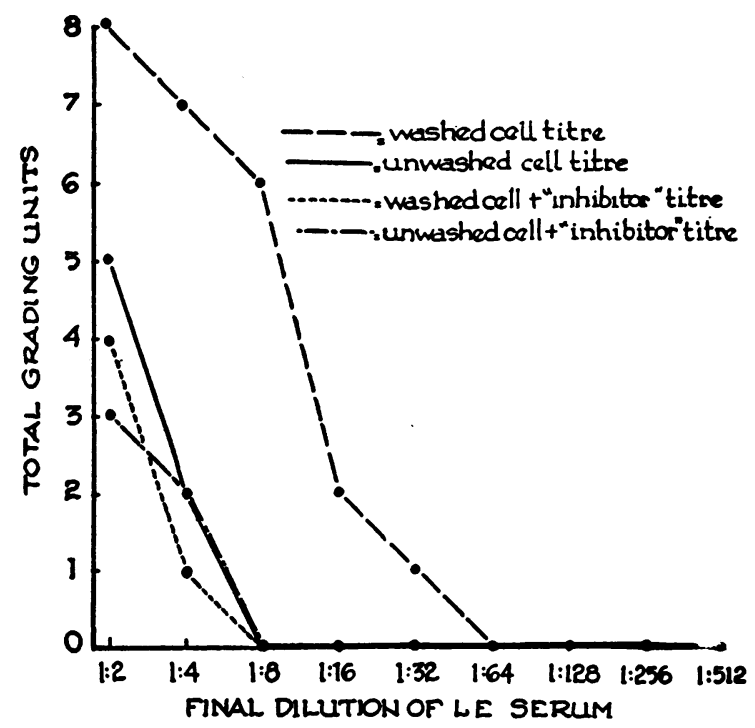

Fig. 4. Effect of Supernatant from $24 \times 10^{\circ}$ WBC per ml. Frozen and Thawed in Normal Serum on Intensity of "L.E. Cell" Phenomenon at Several Dirutions of L.E. Serum (In Normal Serum)

The washed WBC were resuspended in a WBC homogenate or a WBC fraction (see Part I, A for description of fractions). The whole homogenates, and each of the fractions which contained DNase inhibitor ("cytoplasmic fraction," "cytoplasmic supernatant"), but not those without DNase inhibitor activity (chromosomal fraction, cytoplasmic sediment, DNH, DNA, histone, "residual chromosomes"), reduced the intensity of the "L.E. cell" phenomenon in washed WBC (Table III). Slight inhibition of "L.E. cell" transformation of unwashed WBC was also demonstrated (Fig. 4).

In order to test the relationship between inhibition of the "L.E. cell" phenomenon and the con-

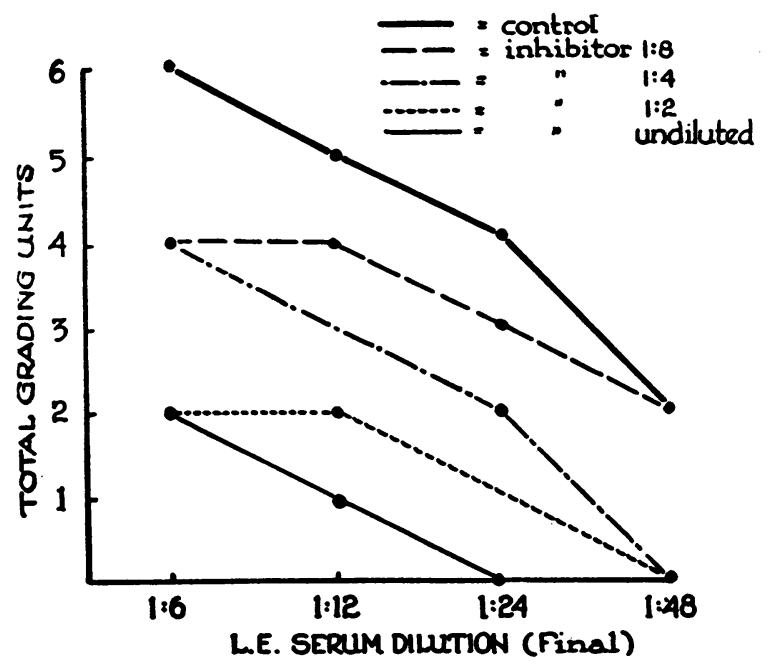

Fig. 5. EFFect of Concentration of INHibitor on the Intensity of the "L.E. Cell" Phenomenon Probuced in Washed WBC by Several Dilutions of L.E. SERUM

centration of the inhibitor, an experiment was performed in which the inhibitor, a homogenate of $24 \times 10^{6}$ WBC per ml. plasma (frozen and thawed), was serially diluted with normal plasma. The control contained normal plasma in place of the inhibitor. The data are presented in Fig. 5, and the percentage inhibition in Fig. 6. The similarity between Fig. 6 and Fig. 2 is apparent. It should be borne in mind that the percentage inhibitions shown in Fig. 6 represent the ratios of the total grading units of the inhibited and uninhibited experiments. This is only a very rough estimate of the degree of inhibition, therefore. Since the

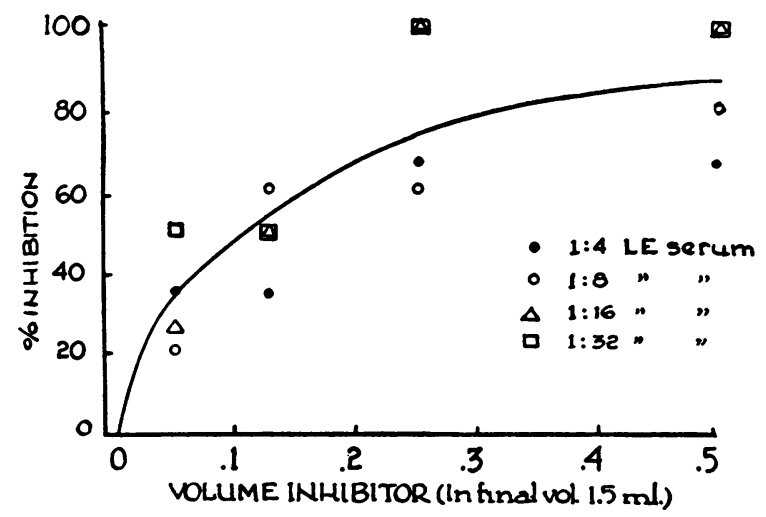

Fig. 6. Degree of Inhibition of "L.E. Cell" PheNOMENON vS. VOLUME (CONCENTRATION) OF INHIBITOR (From Data in Fig. 5) 
final volume is approximately $1.5 \mathrm{ml}$. in the "L.E. cell" experiments, whereas it is $19 \mathrm{ml}$. in the DNase experiments, the greater sensitivity of the DNase system to the inhibitor is obvious.

\section{Physico-chemical properties of "L.E. cell" phenomenon inhibitor}

Like the DNase inhibitor, the "L.E. cell" phenomenon inhibitor was found to be unaffected by a temperature of $56^{\circ} \mathrm{C}$ for 30 minutes, but was destroyed at $100^{\circ} \mathrm{C}$ for 15 minutes. Similarly, dialysis did not impair the inhibition of the "L.E. cell" phenomenon. After repeated use over a period of weeks, which required bringing the material to room temperature for short intervals and refreezing, inhibition of both the serum DNase and of the "L.E. cell" phenomenon became progressively less effective. This was presumed to be

TABLE IV

Effect of anions on "L.E. cell" phenomenon

\begin{tabular}{llllll}
\hline \hline & & \multicolumn{4}{c}{ Result* } \\
\cline { 3 - 6 } Salt & $\begin{array}{c}\text { Concen- } \\
\text { tration }\end{array}$ & Undil.** & $1: 4$ & $1: 16$ & $1: 64$ \\
\hline Sodium Chloride & $0.14 \mathrm{M}$ & 10 & 6 & 3 & 1 \\
Sodium Arsenate & $0.2 \mathrm{M}$ & 10 & 4 & 0 & 0 \\
Potassium Oxalate & $0.2 \mathrm{M}$ & 6 & 1 & 0 & 0 \\
Sodium Citrate & $0.2 \mathrm{M}$ & 5 & 2 & 1 & 0
\end{tabular}

* Total grading score. Maximum is 12 (4 each for "L.E. cells," rosettes, "globs")

** Dilutions indicated are those of the L.E. serum (diluted with normal serum)

due to proteolysis, since, under the conditions described in Part I, D, the "L.E. cell" inhibitor was also destroyed by proteolytic enzymes.

\section{E. Effect of magnesium ion binding anions on "L.E. cell" phenomenon}

Since intracellular DNase is thought to play a part in the production of the "L.E. cell" phenomenon, anionic DNase inhibitors were tested. These ions are thought to act by binding $\mathrm{Mg}^{++}$, which is required for optimal DNase activity. The WBC buttons were suspended in $0.5 \mathrm{ml}$. of the electrolyte solution, followed by $0.5 \mathrm{ml}$. L.E. serum. Thus, the final concentration of the salt was approximately one-third that indicated in Table IV, which presents the observed results. Definite inhibition by citrate, oxalate, and arsenate, in order of decreasing effect was apparent.

\section{DISCUSSION}

The experimental data demonstrate the presence in human leucocytes of an inhibitor for human serum DNase, and an inhibitor of the "L.E. cell" phenomenon.

These inhibitors do not permeate a cellophane membrane, are destroyed by heating to $100^{\circ} \mathrm{C}$ but are stable at $56^{\circ} \mathrm{C}$, are stable at $-20^{\circ} \mathrm{C}$ for several months and at $0-2^{\circ} \mathrm{C}$ for at least several days. They are destroyed by a number of proteolytic enzymes, but not nucleolytic enzymes. Extremes of $\mathrm{pH}$ also destroy the DNase inhibitor. Efforts at purification and further physico-chemical characterization of the factor or factors are in progress.

The DNase inhibitor reveals species specificity to some extent (only in the rabbit is the same degree of inhibition obtained as in the human). It may be suggested that the specificity is due to the requirement for a hypothetical serum co-factor. However, inhibitors prepared by freezing and thawing WBC in their own plasma, which would contain the hypothetical co-factor, reveal the same specificity as do saline extracts. Thus, the specificity is probably a function of differences in DNase from various species. Immunologic differences in DNases have already been demonstrated by McCarty (20).

That the inhibitors are present in the leucocytes is apparent from the method of preparation. The only other elements regularly present are thrombocytes. However, potent inhibitors were obtained from the WBC of a patient with severe thrombocytopenia. The inhibitors are found in the supernatant upon rupturing the cells in saline. Although this fraction is ordinarily regarded as cytoplasmic, it undoubtedly includes some proteins of nuclear origin. The cytological localization of the inhibitors is, therefore, unsettled.

Desoxyribonuclease inhibition by cell extracts has also been reported by others. The inhibitor of yeast DNase which Zamenhof and Chargaff (13), obtained from yeast, resembles the inhibitor in WBC described in this paper in its species specificity (for yeast), in its instantaneous effect upon the enzyme activity, and in its protein nature, but is less stable (destroyed at $56^{\circ} \mathrm{C}$ in 5 minutes). Dabrowska, Cooper and Laskowski (21) and Cooper, Trautmann and Laskowski (22) prepared an inhibitor of bovine DNase from several 
avian and mammalian organs. These inhibitors were also proteins and were very unstable. This instability interferes with the separation of excess DNase activity from the inhibitor content of cell extracts since both DNase activity and inhibitor are destroyed at $56^{\circ} \mathrm{C}$. Thus, these inhibitors differ from ours both in lack of species specificity and in stability.

Henstell and Freedman $(23,24)$ have recently reported on the preparation of an inhibitor of bovine DNase from leucocytes by the dilution of whole blood $1: 100$ or $1: 1000$ with water. Their inhibitor appears to be very similar to that of Laskowski's group in its non-specificity and instability. It differs from that reported by us, because it is potent in very great dilution and is less, rather than more, abundant in immature cells. It is apparent that we failed to observe the inhibitor reported by these authors because of its instability, since several hours were required for the preparation of the inhibitor in leucocytes, and it was not tested on the day of preparation.

Bernheimer and Ruffier (25) isolated a specific DNase inhibitor from streptococci. This inhibitor, however, differs from that described here in being destroyed by ribonuclease but not by proteolytic enzymes, thus indicating its non-protein nature. It appears, then, that we have observed a new inhibitor from mammalian tissues, most closely resembling that described by Zamenhof and Chargaff (13), in yeast.

Close parallelism between the inhibitor of serum DNase described by us and the inhibitor of the "L.E. cell" phenomenon suggest their identity. The two activities are located in the same WBC fraction. They show the same heat stability and are non-dialyzable. Complete correspondence is not observed in the intensity of the effect, in that more nearly complete inhibition of serum DNase than of the "L.E. cell" phenomenon is usually obtained. This, however, may not indicate lack of identity of the inhibitors, since the intracellular DNase is probably less accessible to inhibitor added in vitro, and the intra- and extracellular DNases may not be identical in susceptibility to the inhibitor. Proof of the identity of the inhibitors must await their further purification.

Since the evidence suggests the identity of the intracellular DNase inhibitor and the inhibitor of the "L.E. cell" phenomenon, it is probable that the depolymerization of DNA which characterizes the "L.E. cell" is secondary to a derangement of the intracellular DNase-DNase inhibitor system. This abnormality is not primary in the cell, since it can be induced in leucocytes from a normal individual (26) by serum from a patient with systemic lupus erythematosus. We suggest that the L.E. plasma factor (27), which itself has no DNase activity (5), causes the release of the intracellular DNase from inhibition. The inhibition of the "L.E. cell" phenomenon by anionic DNase inhibitors, as well as by an extract which contains a naturally occurring DNase inhibitor, supports this hypothesis.

This hypothesis led to the development of a "sensitized" "L.E. cell" test, using WBC, which had been washed to remove inhibitor. False positive tests are not produced, perhaps because unbroken WBC contain some inhibitor even after repeated washing. This was demonstrated for the DNase inhibitor. Thus, the L.E. serum factor is still required to elicit the phenomenon.

The fact that mature granulocytes show greater susceptibility to the "L.E. cell" transformation than lymphocytes (28) may be due to the apparent greater inhibitor content of the latter noted in our studies (Table I). Likewise, the lesser susceptibility of immature granulocytes may be attributed to their greater DNase inhibitor content as compared with mature leucocytes.

Observations on the DNase inhibitor content of various tissues, normal and pathological, and at various stages of development are in progress. Some observations on lymphocytes, blasts, and granulocytes have already been referred to above. The possible role of a specific inhibitor of DNase in cellular division, growth, senescence, and the development of tumors, which suggests itself, is under further investigation.

\section{SUMMARY}

1. An inhibitor for human serum DNase has been observed in human leucocytes. It is a protein, soluble in saline, stable at $56^{\circ} \mathrm{C}$. Tested against several species, it is equally effective only against rabbit serum DNase and has little or no influence on some others. In its stability and specificity it differs from other DNase inhibitors previously reported. 
2. An inhibitor for the "L.E. cell" phenomenon has been demonstrated in leucocytes. Evidence which suggests its identity with the DNase inhibitor is presented.

3. A sensitive "L.E. cell" test using washed WBC is described.

4. A mechanism for the "L.E. cell" phenomenon is discussed.

\section{ACKNOWLEDGMENTS}

The technical assistance of Mrs. Mary Eason is gratefully acknowledged.

The encouragement of Dr. Paul Klemperer throughout these studies is deeply appreciated.

\section{REFERENCES}

1. Lee, S. L., Michael, S. R., and Vural, I. L., The L.E. (Lupus erythematosus) cell. Clinical and chemical studies. Am. J. Med., 1951, 10, 446.

2. Hargraves, M. M., Richmond, H., and Morton, R., Presentation of two bone marrow elements: the "tart" cell and the "L.E." cell. Proc. Staff Meet., Mayo Clin., 1948, 23, 25.

3. Kurnick, N. B., The determination of desoxyribonuclease activity by methyl green; Application to serum. Arch. Biochem., 1950, 29, 41.

4. Klemperer, P., Gueft, B., Lee, S. L., Leuchtenberger, C., and Pollister, A. W., Cytochemical changes of acute lupus erythematosus. Arch. Path., 1950, 49, 503.

5. Kurnick, N. B., Pariser, S., Schwartz, L. J., Lee, S. L., and Irvine, W., Studies on desoxyribonuclease in systemic lupus erythematosus: Non-participation of serum desoxyribonuclease in the L.E. phenomenon. J. Clin. Invest., 1952, 31, 1036.

6. Kurnick, N. B., discussion of paper by Sparrow, A. H., Moses, M. J., and Dubow, R. J., Relationships between ionizing radiation, chromosome breakage and certain other nuclear disturbances. Exptl. Cell Res., 1952, 2, 266.

7. Kurnick, N. B., Schwartz, L. J., Pariser, S., Lee, S., and Irvine, $W$., The role of desoxyribonuclease and a nuclease inhibitor from leucocytes in the lupus erythematosus cell phenomenon. J. Clin. Invest., 1952, 31, 645.

8. Sorof, S., and Cohen, P. P., Modified semi-microand micro-Waring blendors for low temperature use. Exptl. Cell Res., 1951, 2, 299.

9. Mirsky, A. E., and Ris, H., Isolated chromosomes. J. Gen. Physiol., 1947, 31, 1.

10. Mirsky, A. E., and Ris, $H$., The chemical composition of isolated chromosomes. J. Gen. Physiol., 1947, $31,7$.

11. Mirsky, A. E., and Pollister, A. W., Chromosin, a desoxyribose nucleoprotein complex of the cell nucleus. J. Gen. Physiol., 1946, 30, 117.
12. Kurnick, N. B., Desoxyribonuclease activity of sera of man and some other species. Arch. Biochem. and Biophys., in press.

13. Zamenhof, S., and Chargaff, E., Studies on the desoxypentose-nuclease of yeast and its specific cellular regulation. J. Biol. Chem., 1949, 180, 727.

14. Catcheside, D. G., and Holmes, B., The action of enzymes on chromosomes. Symp. Soc. Exptl. Biol., Cambridge, 1947, 1, Nucleic Acid, 225.

15. Maver, M. E., and Greco, A. E., The nuclease activities of cathepsin preparations from calf spleen and thymus. J. Biol. Chem., 1949, 181, 861.

16. Brown, K. D., Jacobs, G., and Laskowski, M., The distribution of nucleodepolymerases in calf thymus fractions. J. Biol. Chem., 1952, 194, 445.

17. Webb, M., Use of desoxyribonuclease inhibitors in the isolation of desoxyribonucleic acids. Nature, 1952, 169, 417.

18. Gomori, G., Buffers in the range of $\mathrm{pH} 6.5$ to 9.6 . Proc. Soc. Exper. Biol. \& Med., 1946, 62, 33.

19. Kunitz, M., Isolation of crystalline desoxyribonuclease from beef pancreas. Science, 1948, 108, 19.

20. McCarty, M., Purification and properties of desoxyribonuclease isolated from beef pancreas. J. Gen. Physiol., 1946, 29, 123.

21. Dabrowska, W., Cooper, E. J., and Laskowski, M., A specific inhibitor for desoxyribonuclease. J. Biol. Chem., 1949, 177, 991.

22. Cooper, E. J., Trautmann, M. L., and Laskowski, M., Occurrence and distribution of an inhibitor for desoxyribonuclease in animal tissues. Proc. Soc. Exper. Biol. \& Med., 1950, 73, 219.

23. Henstell, H. H., and Freedman, R. I., The viscosimetric determination of desoxyribonuclease inhibition. Cancer Res., 1952, 12, 341.

24. Henstell, H. H., Freedman, R. I., and Ginsburg, B., An inhibitor of desoxyribonuclease in human white blood cells and bone marrow cells and its relationship to cellular maturity. Cancer Res., 1952, 12, 346.

25. Bernheimer, A. W., and Ruffier, N. K., Elaboration of desoxyribonuclease by streptococci in the resting state and inhibition of the enzyme by a substance extractable from the cocci. J. Exp. Med., 1951, 93, 399.

26. Berman, L., Axelrod, A. R., Goodman, H. L., and McClaughry, R. I., So-called "lupus erythematosus inclusion phenomenon" of bone marrow and blood. Morphologic and serologic studies. Am. J. Clin. Path., 1950, 20, 403.

27. Haserick, J. R., Lewis, L. A., and Bortz, D. W., Blood factor in acute disseminated lupus erythematosus; I. Determination of gamma globulin as specific plasma fraction. Am. J. M. Sc., 1950, 219, 660.

28. Rohn, R. J., and Bond, W. H., Some supravital observations on the "L.E." phenomenon. Am. J. Med., 1952, 12, 422. 